\title{
EFFECT OF BLANCHING METHODS ON DRYING KINETICS OF BELL PEPPER
}

\author{
Tunde-Akintunde $\mathrm{TY}^{1 *}$, BO Akintunde ${ }^{2}$ and A Fagbeja ${ }^{1}$
}

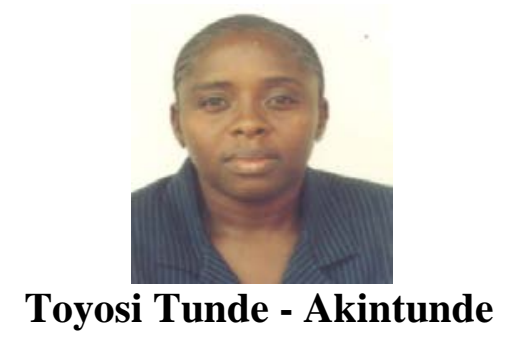

* Corresponding author. Email: toyositunde@yahoo.co.uk

${ }^{1}$ Department of Food Science and Engineering, Ladoke Akintola University of Technology, P.M.B. 4000, Ogbomoso, Oyo State, Nigeria.

${ }^{2}$ Federal College of Agriculture, I.A.R. and T., P.M.B. 5029, Ibadan, Oyo State, Nigeria. 


\section{ABSTRACT}

Various blanching methods and drying temperatures were applied to bell pepper (Capiscum annum) to investigate the effect on its drying characteristics. Pepper (Capiscum annum) is an abundant and cheap source of vitamins, minerals and fibre. However, its high moisture content makes it susceptible to deterioration. The most common method of preservation is drying but the dried products obtained are of reduced nutritional qualities. Pretreatment of pepper before drying improves the quality of the dried pepper and increases its drying rate. Steam and water blanching as a form of pretreatment has been reported to increase drying rate and improve the quality of dried products but there is not much information on other types of oil/water blanching methods. The effect of blanching (steam, water, palm oil/water and groundnut oil/water) as a pretreatment on the drying kinetics of bell pepper dried at temperatures of 50,60, 70, 80 and $90^{\circ} \mathrm{C}$, was studied. Drying of raw untreated bell pepper was taken as a control. The results indicate that water removal at the initial stage of the drying process was highest and there was a rapid decrease as drying continued until equilibrium was reached at the end of process. The blanched samples generally had higher drying rates $($ at $\mathrm{p}<0.05)$ than the untreated samples. The values for the drying rate for steam and water blanched samples were higher (but not at $\mathrm{p}<0.05$ ) than the drying rates for samples blanched in oil/water mixtures. The drying rate as well as effective moisture diffusivity, $\mathrm{D}_{\text {eff }}$, increased with increasing drying temperature. Values of $D_{\text {eff }}$ varied from $3.55 \times 10^{-9} \mathrm{~m}^{2} / \mathrm{s}$ to $2.34 \times 10^{-9} \mathrm{~m}^{2} / \mathrm{s}$ with the highest being SB (steam blanched) at $80^{\circ} \mathrm{C}$ and the lowest UB (unblanched) at $50^{\circ} \mathrm{C}$. The drying process took place mainly in the falling rate period. The activation energies varied from 39.59 to $83.87 \mathrm{~kJ} / \mathrm{mol}$, with $\mathrm{PB}$ (palm oil/water blanched) samples having the lowest and UB having the highest Ea value. The lower values for pretreated samples imply that water movement from the internal regions is faster in pretreated samples. This suggests that blanching as a method of pretreatment generally increases water diffusion.

Key words: Blanching, Pre-treatment, Bell pepper, Oven drying 


\section{INTRODUCTION}

Pepper (Capiscum annum) is an important vegetable crop because it provides an abundant and cheap source of vitamins, minerals and fibre [1]. It is also highly rich in ascorbic acid. Pepper is a seasonal crop and capsicum pepper is classified as a perishable crop that deteriorates fast after few days of harvest due to its high moisture content [1]. The most common method of preservation for pepper is by drying which is an energy-intensive process. The main objective for drying is the reduction of the moisture content to a level, which allows safe storage over an extended period thus extending the shelf-life [2]. Dried products also have other advantages over fresh food products, which include reduced bulk, and hence are easier to transport and package [1]. Drying is carried out traditionally by sun-drying because it is a cheap, simple method that needs low capital investments. The main disadvantage of sun-drying are that it is tedious, requires long drying time and is subject to changes in weather conditions [3]. The use of alternative drying methods such as industrial drying methods (hot-air and solar drying) to replace the traditional sun-drying technique has been observed to help overcome the disadvantages of sun-drying.

Drying of food usually results in loss of nutrients and other undesirable changes, which include discolouration and browning; thus dried products obtained are of reduced nutritional quality [2]. Knowledge of the type of pretreatment methods that can improve the quality of dried products and the drying rate materials is necessary in order to optimise the drying process. During the drying process, the rate at which drying takes place decreases as drying progresses and this affects the drying kinetics of the crop. Therefore, another factor that is required for optimization of the drying process is the knowledge of the drying characteristics of food [4, 5]. A number of studies have been carried out which have identified processing parameters, including drying temperature and use of various types of pretreatment, as having a significant effect on the on the drying kinetics of fruits and vegetables $[3,4,6,7,8]$.

The challenge of reducing drying time and undesirable changes has led to the development of various pretreatment techniques. Pretreatment of food materials which includes; blanching, chemical pretreatment, osmotic dehydration, soaking in ascorbic acid before or on drying have been investigated to improve the effect of drying and give eventual dried products of good nutritional quality [5, 9, 10, 11]. Pretreatment of fruits and vegetables prior to drying has been used to overcome the wax barrier on fruits or vegetables and thus reducing drying time [12].

Blanching as a pretreatment is a short-time heat-treatment generally applied to fruits and vegetables primarily to inactivate natural enzymes [13]. When used for pretreating of vegetables, it destroys enzymes and loosens tissues which sometimes fixes the natural colour and affords more rapid drying. Blanching can be done in a number of ways which usually includes water, steam and oil blanching [9]. The addition of oil to water used for blanching helps to replace the initial outer wax layer, which is beneficial because of the protection it offers the fruit or vegetable from environmental and external factors. Biekman et al. [14] observed that shrinkage in blanched tissues which is due to the contraction of bio-polymers during blanching is temperature

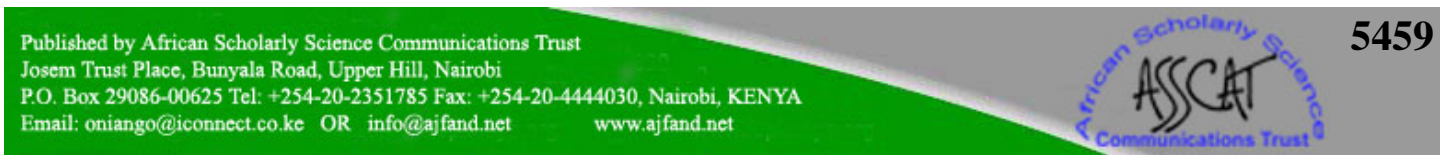




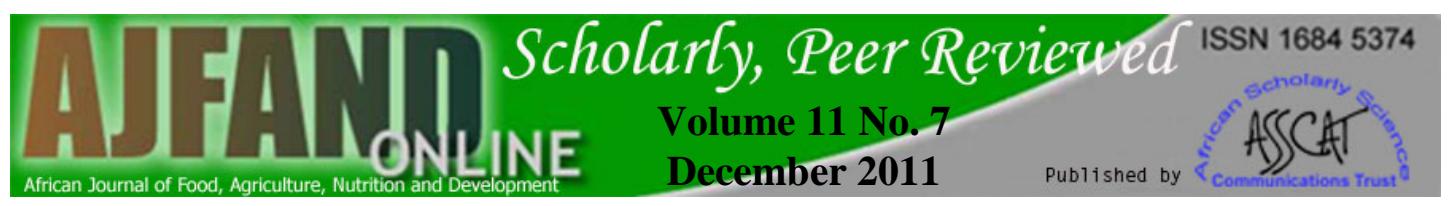

dependent. It opens up plant cells which exude fluids with simultaneous loss of solutes. Blanching affects the distribution of soluble components within the tissues during drying. This also results in the leakage of soluble components to the surrounding environment (water) and loss of these solutes affects the rate of drying. Researchers have reported that blanching increases the drying rate of some fruits including peach slices (Prunus persica L.), red pepper (Capiscum annum) and carrot cubes (Daucus carota L.) $[5,9,15,16]$. Although there has been a lot of work done on the effects of steam and water blanching on the drying rate of fruits and vegetables, not much has been done on other types of blanching methods especially oil blanching. This study investigated the effect of various blanching methods on the drying characteristics of bell pepper (Capiscum annum). This was achieved by determining and comparing the drying rate, effective moisture diffusivity and activation energy values for the various blanching methods and drying temperature.

\section{MATERIALS AND METHODS}

\section{Experimental procedure}

Freshly harvested red bell pepper (Capiscum annum) samples selected to conform to nearly the same dimension (width, length and breadth), without blemish or blight, were purchased from Otan-ile market in Ogbomoso, Nigeria. The samples were washed, drained, and all extraneous materials removed completely before they were sliced into two. The samples were divided into sets of $200 \mathrm{~g}$ weight. For the blanching pretreatments for inactivation of enzymes, the samples were:

(i) Submerged in boiling water for 3 minutes, drained and cooled immediately in tap water before being taken to the oven for drying (WB).

(ii) Steamed over boiling water in a water bath (WBH 14/F2, England) for 3 minutes, drained and cooled immediately in tap water before taken to the oven for drying (SB).

(iii) Dipped for 3 minutes in a homogenized mixture of palm oil and water of ratio 1:20 (v/v) with $0.1 \mathrm{~g}$ of butylated hydroxyl anisole (BHA) heated to $95^{\circ} \mathrm{C}$ [9] before being placed in the oven for drying (PB).

(iv) Dipped for 3 minutes in a homogenized mixture of groundnut oil and water of ratio 1:20 (v/v) with $0.1 \mathrm{~g}$ of butylated hydroxyl anisole (BHA) heated to $95^{\circ} \mathrm{C}$ before being placed in the oven for drying (GB).

(v) The samples that were unblanched (UB) were used as the control.

\section{Drying procedure}

The samples were dried in a hot-air dryer (Gallenkamp, UK) having three tiers of trays. Perforated trays having an area of approximately $0.2 \mathrm{~m}^{2}$ were placed on each tier and the trays were filled with a single layer (of about $2 \mathrm{~mm}$ thick) of the pretreated pepper samples. The hot air passed across the surface and perforated bottom of the drying material. The drying of bell pepper (Capiscum annum) was conducted at five temperatures $\left(50,60,70,80\right.$ and $\left.90^{\circ} \mathrm{C}\right)$ with fixed airflow $(2.0 \mathrm{~m} / \mathrm{s})$. The drying experiment involving untreated bell pepper samples was also performed 
under the same conditions. The drying was carried out until constant weight was reached with three successive readings. The dryer was adjusted to the selected temperature for about an hour before the start of experiment to achieve the steady state conditions. The direction of air flow was perpendicular to the samples. Weight loss of samples was measured at various time intervals, ranging from $30 \mathrm{~min}$ at the beginning of the drying (for the first two hours) to 120 min during the last stages of the drying process by means of a digital balance (Mettler, Model BB3000) with an accuracy of $\pm 0.01 \mathrm{~g}$. The experiments were repeated in triplicate and the average moisture ratio at each value was used to draw drying curves.

The reduction of moisture ratio with drying time was used to analyse the experimental drying data for pretreated and untreated pepper. This is because the moisture ratio curve explains the drying behaviour better than the moisture content curve, and also because the value at the beginning of the drying experiment was one in each of the experiments using the moisture ratio values $[8,10]$.

The moisture ratio during drying was determined as follows $[3,7,12]$ :

$$
\mathrm{M}_{\mathrm{R}}=\frac{\mathrm{M}-\mathrm{M}_{\mathrm{e}}}{\mathrm{M}_{\mathrm{i}}-\mathrm{M}_{\mathrm{e}}}=\exp (-K t)
$$

Where $\mathrm{M}_{\mathrm{R}}=$ moisture ratio, $\mathrm{M}_{\mathrm{e}}=$ equilibrium moisture content (dry basis), $\mathrm{M}_{\mathrm{i}}=$ initial moisture content (dry basis), $\mathrm{M}=$ moisture content at time $\mathrm{t}, \mathrm{K}=$ constant.

For the mathematical analysis, it was assumed that the moisture gradient driving force during drying was a liquid concentration gradient. The effect of heat transfer was neglected as a simplifying assumption. For all experimental conditions, the value of $\left(\mathrm{M}-\mathrm{M}_{\mathrm{e}}\right) /\left(\mathrm{M}_{\mathrm{o}}-\mathrm{M}_{\mathrm{e}}\right)$ expressing dimensionless moisture content were obtained.

The drying rate (DR) was determined as follows:

$$
D R=\frac{M_{t+d t}-M_{t}}{d t}
$$

Where $\mathrm{M}_{\mathrm{t}+\mathrm{dt}}$ is moisture content at $t+d t$ (dry basis), $t$ is time (min).

\section{Effective moisture diffusivity}

Fick's diffusion equation for objects with slab geometry is used for calculation of effective moisture diffusivity. As the peppers were dried after slicing, the samples were considered to approximate a slab geometry. The Fick's equation is expressed as [17]:

$$
M_{R}=\frac{8}{\pi^{2}} \exp \frac{-\pi^{2} D_{e f f} t}{4 L^{2}}
$$

where $M_{R}$ is the dimensionless moisture ratio, $D_{\text {eff }}$ the effective moisture diffusivity $\left(\mathrm{m}^{2} \mathrm{~s}^{-1}\right)$, $\mathrm{t}$ the time of drying ( $\left.\mathrm{s}\right), \pi$ is a constant and $\mathrm{L}$ is half of the slab thickness (m). 
$D_{\text {eff }}$ can be calculated from the plot of $\ln \left(M-M_{e}\right) /\left(M_{i}-M_{e}\right)$ against time (t) for different process conditions [5]. The effective diffusivity of the peppers at different temperatures was calculated thus,

$\operatorname{Slope}(k)=\frac{D_{e f f} \pi^{2}}{4 L^{2}}$

The effect of temperature on diffusivity can be described by an Arrhenius-type equation:

$$
D_{\text {eff }}=D_{o} \exp \left(-\frac{E_{a}}{R(T+273.15)}\right)
$$

where $D_{0}$ is the pre-exponential factor of the Arrhenius equation $\left(\mathrm{m}^{2} / \mathrm{s}\right), E_{a}$ is the activation energy for the moisture diffusion $(\mathrm{kJ} / \mathrm{mol}), \mathrm{R}$ is the ideal gas constant (8. $3143 \mathrm{~kJ} / \mathrm{mol} \mathrm{K})$, and $\mathrm{T}$ is the temperature in $\left({ }^{\circ} \mathrm{C}\right)$.

\section{Activation Energy}

The activation energy was calculated by plotting the graph of natural logarithm of $\mathrm{D}_{\text {eff }}$ $\left(\mathrm{Ln} \mathrm{D}_{\text {eff }}\right)$ versus the reciprocal of the temperature $(1 /(\mathrm{T}+273.15))$, and obtaining the slope.

\section{RESULTS}

\section{Drying characteristics}

The drying rate curves of the pretreated bell pepper (Capiscum annum) at the drying temperatures of 50,60, 70, 80 and $90^{\circ} \mathrm{C}$ respectively are shown in Figures $1-5$. At the initial drying stage, water removal was highest and this water removal decreased rapidly as drying continued until at the end of drying when no more water was removed. At this point the moisture content is assumed to reach equilibrium. The drying rates for unblanched (UB) samples were generally lower than that of other samples. The drying rates for SB and WB samples were, however, generally higher than that of the other oil/water blanching methods. 


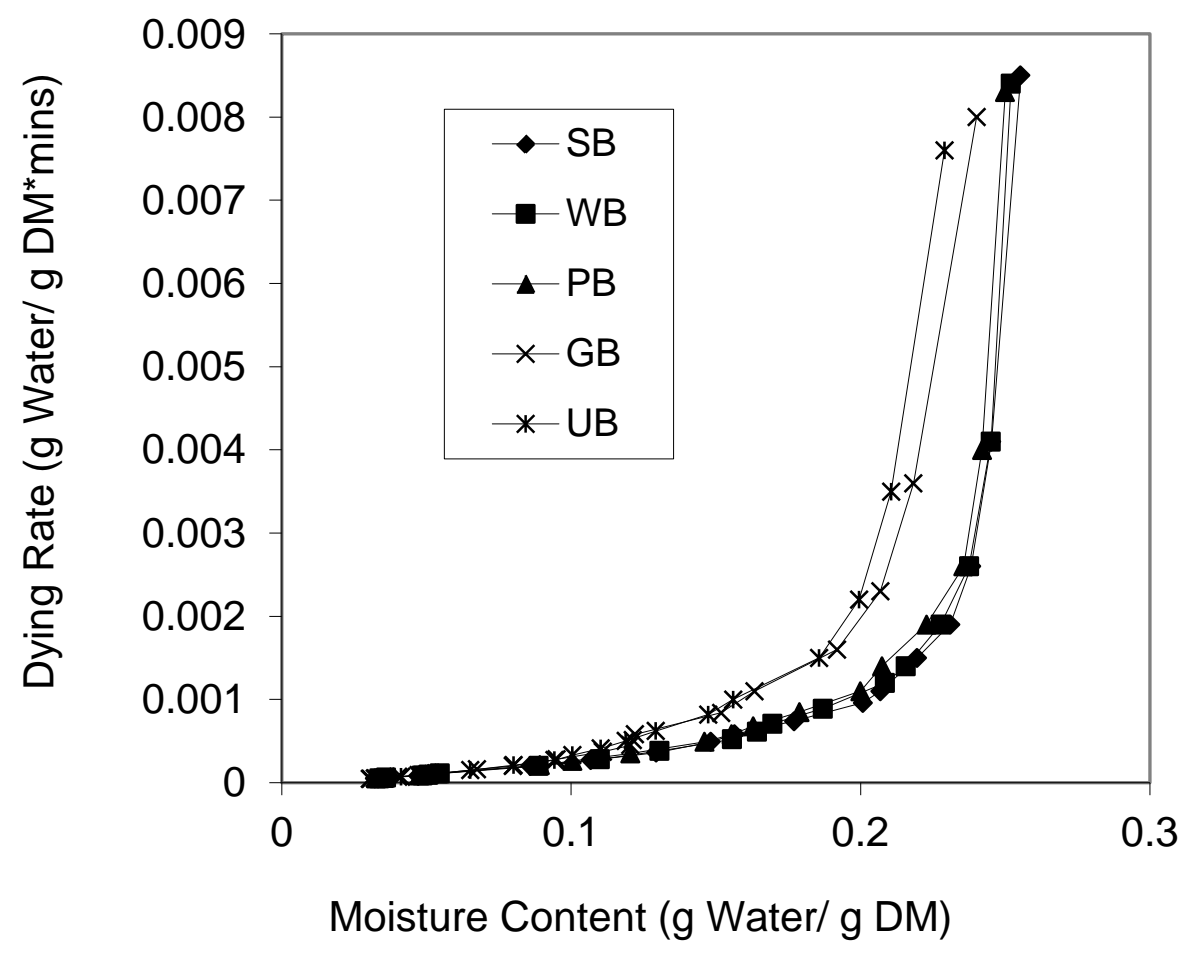

Figure 1: Drying rate of bell pepper dried at $50^{\circ} \mathrm{C}$ under various pretreatments (SB- steam blanched, WB- water blanched, PB- Palm oil and water blanched, GB- Groundnut oil and water blanched, UB- Unblanched) 


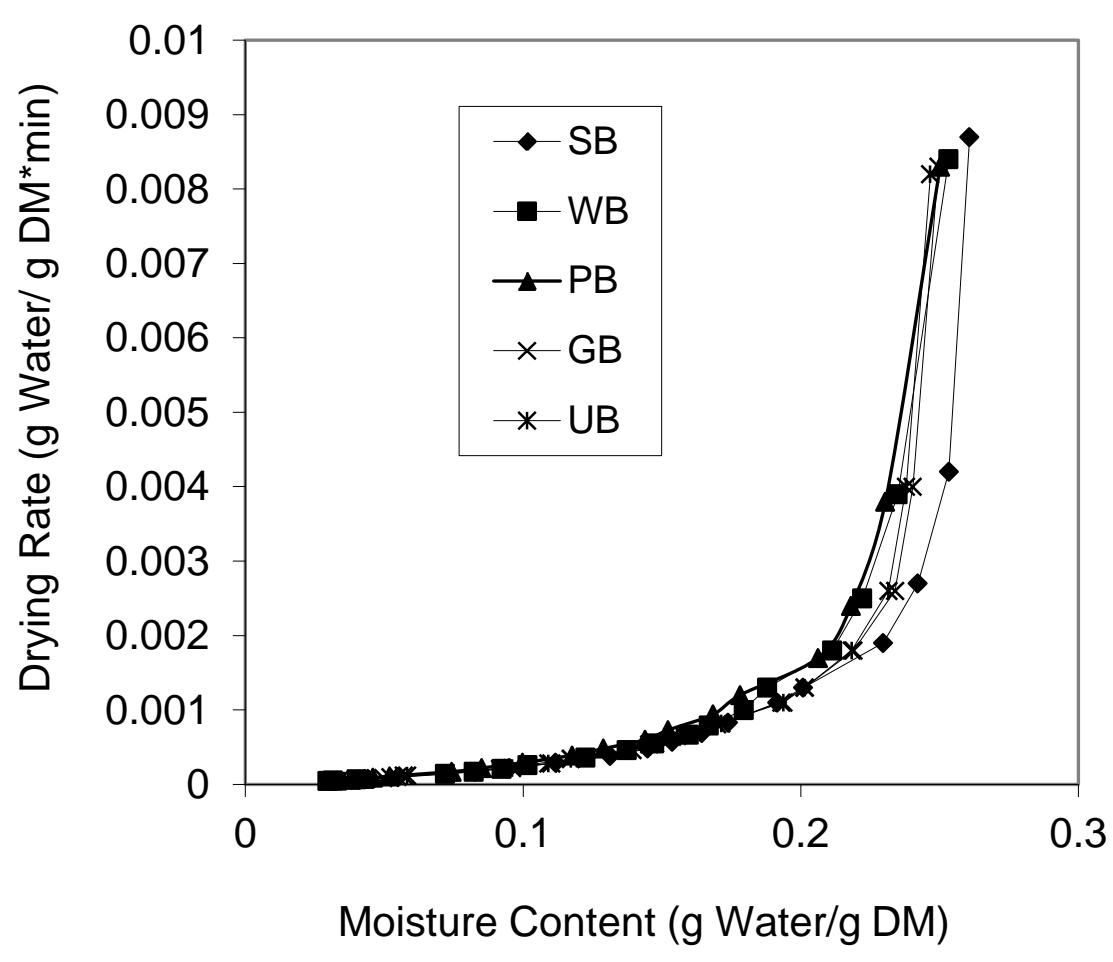

Figure 2: Drying rate of bell pepper dried at $60^{\circ} \mathrm{C}$ under various pretreatments (SB- steam blanched, WB- water blanched, PB- Palm oil and water blanched, GB- Groundnut oil and water blanched, UB- Unblanched) 


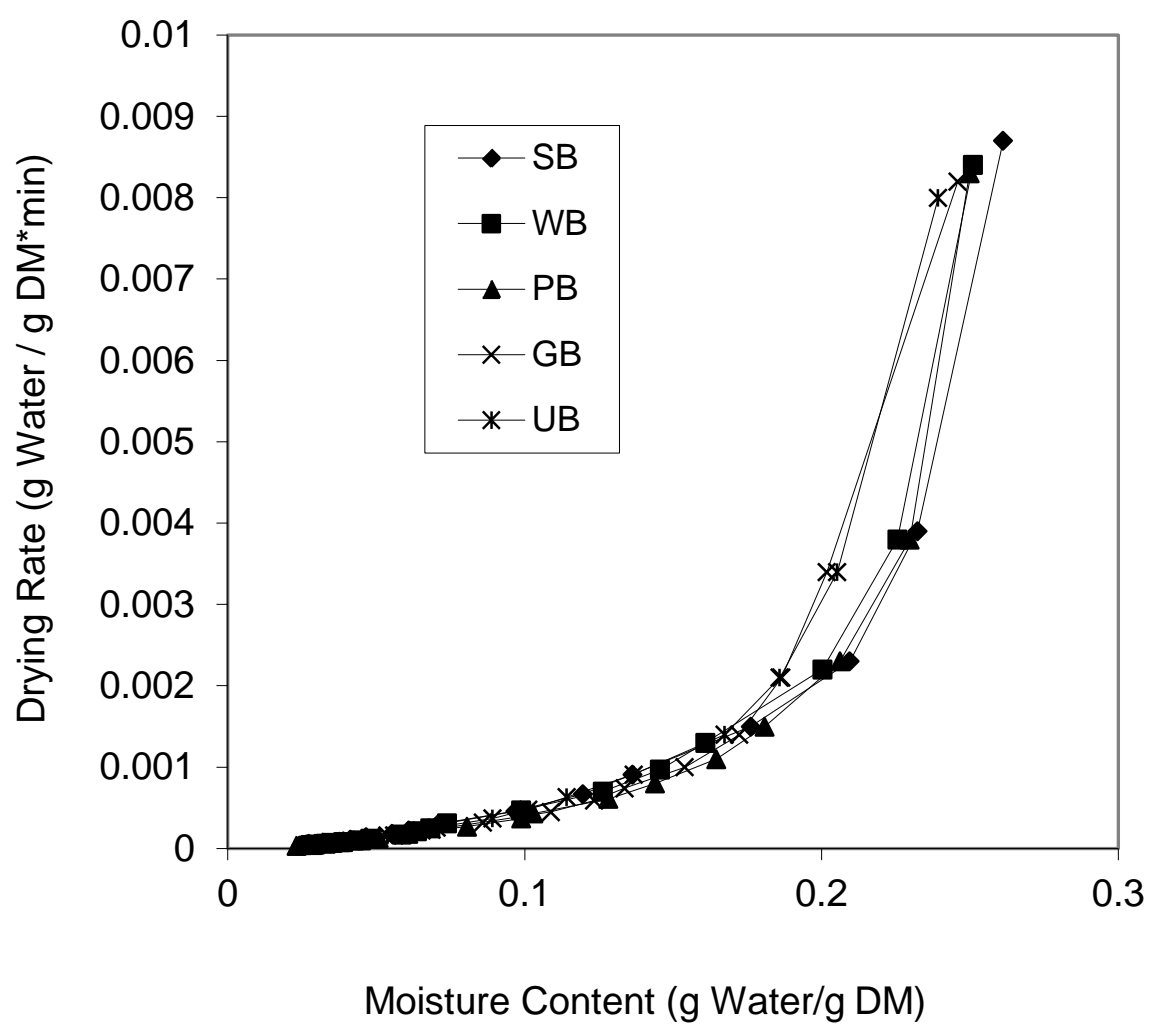

Figure 3: Drying rate of bell pepper dried at $70^{\circ} \mathrm{C}$ under various pretreatments (SB- steam blanched, WB- water blanched, PB- Palm oil and water blanched, GB- Groundnut oil and water blanched, UB- Unblanched) 


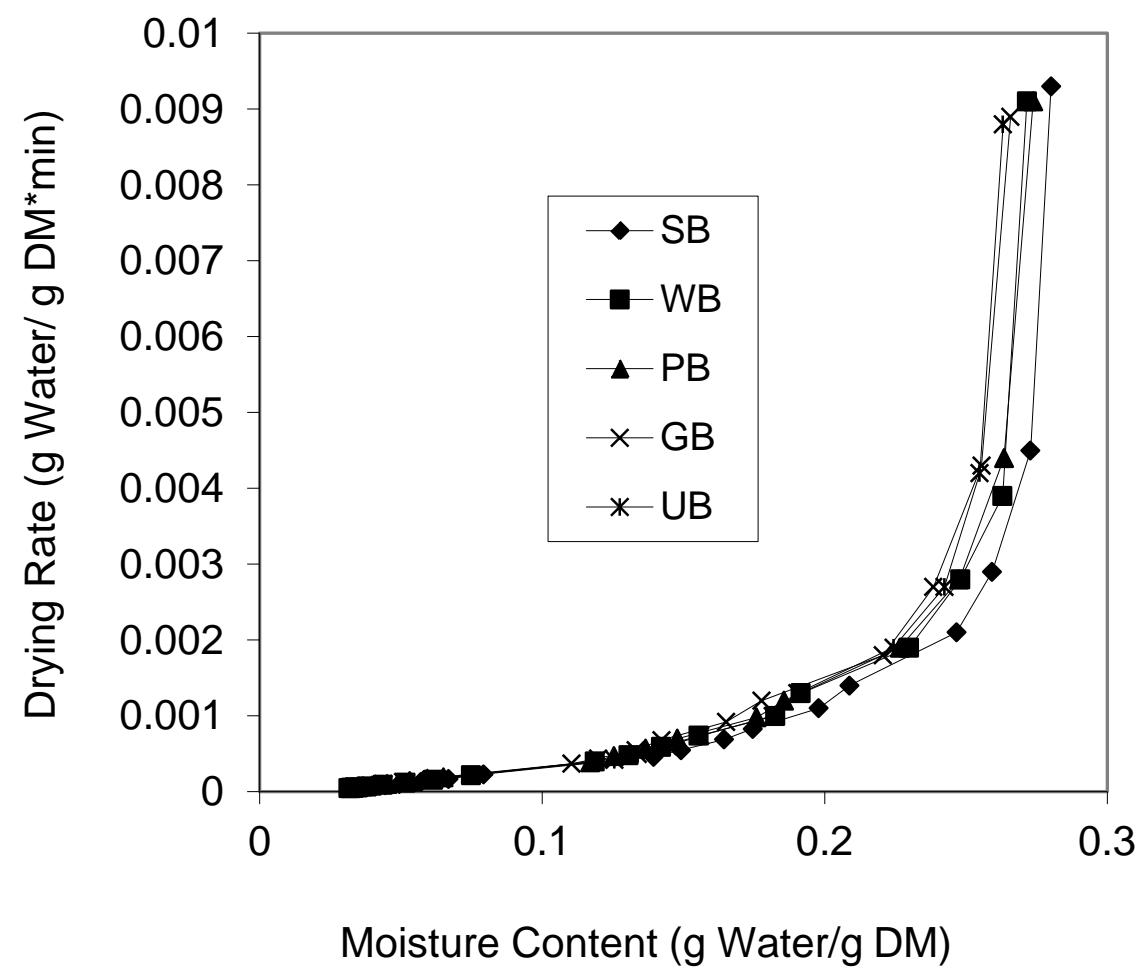

Figure 4: Drying rate of bell pepper dried at $80^{\circ} \mathrm{C}$ under various pretreatments (SB- steam blanched, WB- water blanched, PB- Palm oil and water blanched, GB- Groundnut oil and water blanched, UB- Unblanched) 


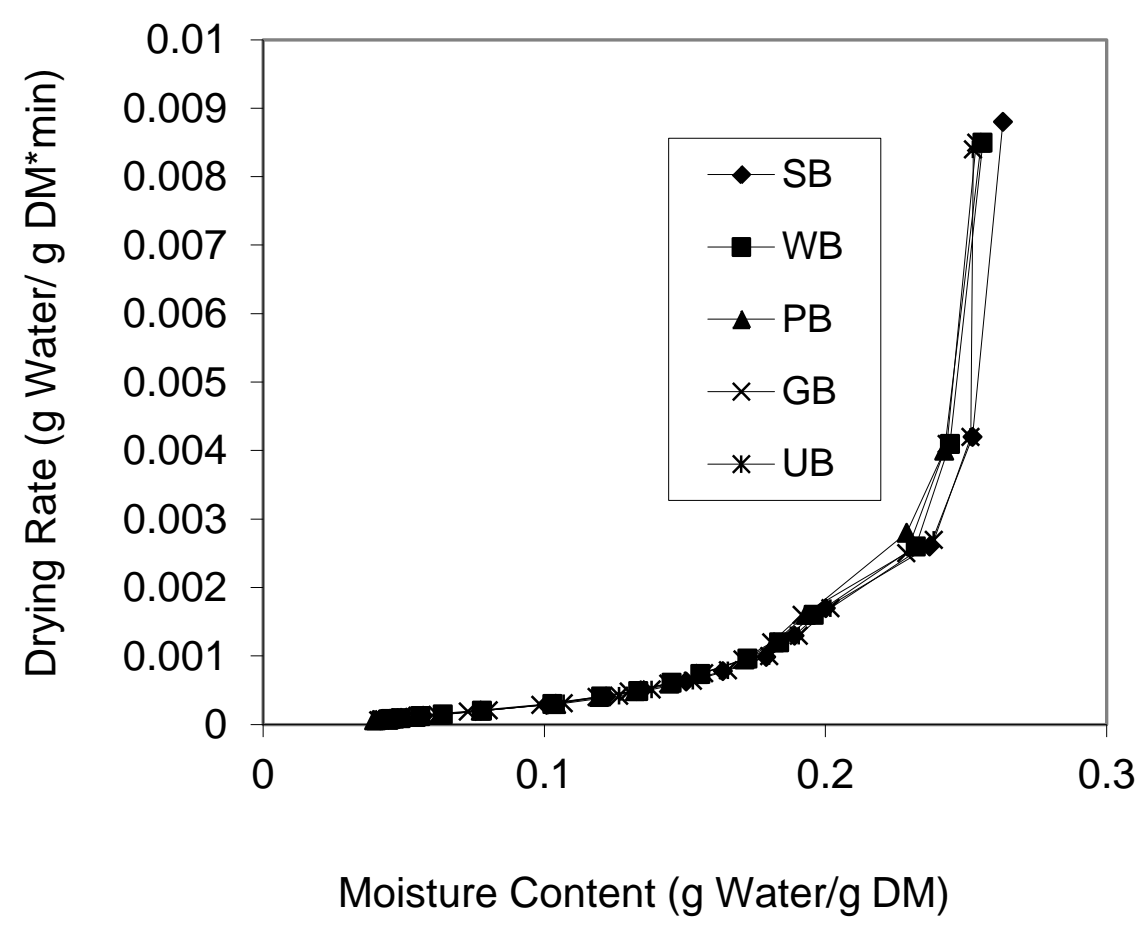

Figure 5: Drying rate of bell pepper dried at $90^{\circ} \mathrm{C}$ under various pretreatments (SB- steam blanched, WB- water blanched, PB- Palm oil and water blanched, GB- Groundnut oil and water blanched, UB- Unblanched)

\section{Effective Moisture Diffusivity}

Drying was done in the falling rate period. In this period, drying was controlled by internal moisture transfer resistance from peppers such that experimental values can be interpreted according to the Fick's diffusion model. The slope of the logarithmic plots for each experimental condition was used to calculate $D_{\text {eff }}$ and the values and their regression coefficients $\mathrm{R}^{2}$ are recorded in Table 1 . The moisture diffusivity value, $\mathrm{D}_{\text {eff }}$ increased with increase in temperature. Samples dried at $80^{\circ} \mathrm{C}$ had the highest $D_{\text {eff }}$ value of $3.55 \times 10^{-9} \mathrm{~m}^{2} / \mathrm{s}$ while the lowest values were obtained from drying at $50^{\circ} \mathrm{C}$ as indicated in Table 1.

\section{Activation Energy}

The activation energies varied from 39.59 to $83.87 \mathrm{~kJ} / \mathrm{mol}$ with PB samples having the lowest and UB having the highest Ea value (Table 2). This shows that pre-treated bell pepper (Capiscum annum) had slightly lower activation energy compared to untreated pepper.

\section{DISCUSSION}

The lower drying rates for UB samples compared to the other blanching pretreatment methods showed that the blanching operation generally increased the drying rate. This is similar and confirms the observations on peach slices (Prunus persica L.), red 
pepper (Capiscum annum) and carrot cubes (Daucus carota L.) [5, 9, 15, 16]. This is due to the fact that blanching of the pepper samples increased the rate of drying by aiding water loss from the internal regions of the product to its surface during the drying process [9]. This is because of the structural change in the product during blanching, which causes the pore openings of the food material to become enlarged thus increasing the rate at which water is evaporated [16]. This is similar to the observations of Karathanos and Belessiotis [18] who reported that pretreatment reduced the effect of skin thickness, which is a normal resistance to water loss at the surface of the product. This resulted in a faster drying when compared to the untreated or control samples. This is an indication that the various types of blanching pretreatment employed in this study enhance moisture evaporation and hence improves drying rate. Thus, the use of blanching as a pretreatment can be used to achieve a more rapid drying of bell pepper (Capiscum annum).

The lower drying rate for oil and water blanching methods when compared to steam and water blanching is probably due to the fact that the presence of palm or groundnut oil in the blanching mixture for PB and GB samples resulted in a type of coating of the surface by wax-like oil. The presence of this coating and the well-known hydrophobicity of palm or groundnut oil all acted to reduce the moisture movement slightly. Similar effect of reduction of moisture movement due to surface coating was also observed during the drying of seedless grapes [19]. However, the effect of blanching pretreatment (such as enhancement of moisture evaporation and improvement of drying rate) resulted in higher drying rate for the oil and water blanching methods, which is desirable, when compared with untreated pepper. The coating that developed on the pretreated pepper during the oil and water blanching of pepper can be used to help replace the initial outer wax layer, which offers benefits such as protection to the fruit or vegetable from environmental and external factors.

Though the initial moisture content of the five samples was quite high, it was observed that the constant rate drying period was absent generally. The overall drying process took place within the regime of the falling rate drying period. The same result was found during the drying of peach slices (Prunus persica L.), onions (Allium cepaL), pestil, green and red pepper (Capsicum annuum L.) [5, 17, 20, 21]. The absence of a constant rate drying period in the drying of pepper shows that the rate of moisture evaporation from the surface is higher than the rate of moisture diffusion to the surface from the internal regions. This indicates that moisture transfer in the solids is controlled by a diffusion mechanism.

The increase in drying rate with increase in heating temperature is as expected and the higher the drying temperature the higher the diffusion coefficient. This is because higher air drying temperatures will result in greater vapour gradients at the food surface which will invariably lead to a higher rate of moisture evaporation at the food/air interface. This higher moisture evaporation rate will cause a higher rate of moisture diffusion from the internal regions of the pepper to the surface which increases the diffusion coefficients. The increase in moisture diffusivity value, $\mathrm{D}_{\text {eff }}$ with increase in temperature is similar to observations for dried pestil and pepper (Capsicum annuum L.) [17, 21]. In these reported cases, samples that were blanched 
had higher drying rates than the untreated ones. Doymaz [4] and Kingsly et al. [5] reported a similar pattern of increase in drying rate for pretreated samples of apricots (Prunus armeniaca L.) and peach (Prunus persica L.).

The unexpected reduction in effective moisture diffusivity at $90^{\circ} \mathrm{C}$ may be possibly due to a critical structural change, which occurred in the sample between treatments at $80^{\circ} \mathrm{C}$ and those at $90^{\circ} \mathrm{C}$. However, the resulting values were within the general range of $10^{-9}-10^{-11} \mathrm{~m}^{2} / \mathrm{s}$ reported for dried food materials [5]. These recorded values are comparable to that obtained for hot air drying of banana slices (Musa cavendishii, var. enana) at $60^{\circ} \mathrm{C}\left(8.3310^{-10} \mathrm{~m}^{2} / \mathrm{s}\right)$ [22], hot air drying of mulberry (Morus alba L.) $\left(2.32 \times 10^{-10}-2.76 \times 10^{-9}\right)$ [23], hot air drying of okra (Abelmoschus esculentus L.) $\left(4.28 \times 10^{-10}-6.8 \times 10^{-9}\right)$ [24] and hot air drying of pestil $\left(4.76 \times 10^{-11}-3.76 \times 10^{-10}\right)$ [17].

The slightly lower activation energy of pretreated pepper compared to untreated pepper is an indication that less energy is used during the drying of all the bell pepper samples subjected to blanching pretreatment when compared with drying of untreated pepper. This is because water travels faster in pretreated samples [5, 9]. This is an indication that blanching as a pretreatment can be used to optimize the drying process of pepper in terms of energy utilization. This confirms the fact that blanching generally increases water diffusion from the internal regions to the product surface during drying which is as reported for other fruits $[5,9,15,16]$. The activation energy values for pretreated and untreated pepper are higher than the activation energies of green peas (Pisum sativum) drying $(28.40 \mathrm{~kJ} / \mathrm{mol})$ [25] and that of pre-treated and untreated tomatoes (Lycopersicon esculentum Mill) drying (17.40 and $32.94 \mathrm{~kJ} / \mathrm{mol}$ ) [12], while the activation energies of red chilli (Capscium frutscens) drying (41.95 $\mathrm{kJ} / \mathrm{mol}$ ) [26] and okra (Abelmoschus esculentus L.) drying (51.26 kJ/mol) [27] are within the range obtained.

\section{CONCLUSION}

- The blanching pretreatment increased the drying rates for pepper samples. The untreated samples generally had lower drying rates than those of the pretreated samples.

- The drying rates for samples immersed in the blanching mixture containing palm or groundnut oil were generally lower than the drying rates observed from samples immersed in other blanching media.

- There was no evidence of the constant rate period in the drying curve, which indicates that the overall drying process took place in the falling rate period. This is an indication that drying of the treated and untreated pepper is controlled by internal moisture transfer resistance from peppers.

- Samples dried at $80^{\circ} \mathrm{C}$ had the highest $\mathrm{D}_{\text {eff }}$ value while the lowest values were obtained from drying at $50^{\circ} \mathrm{C}$. 


\section{RECOMMENDATION}

- The use of blanching as a pretreatment during the drying of peppers is recommended because it reduces the time and rate of drying. Reduction in time and rate of drying results in final dried products of higher quality.

- Also, since the use of blanching as a pretreatment optimizes the drying process of pepper in terms of energy utilization, it is recommended for use by local processors in order to reduce the energy involved in pepper drying. Energy reduction during drying will reduce the production cost which will result in higher earnings by the processors. 


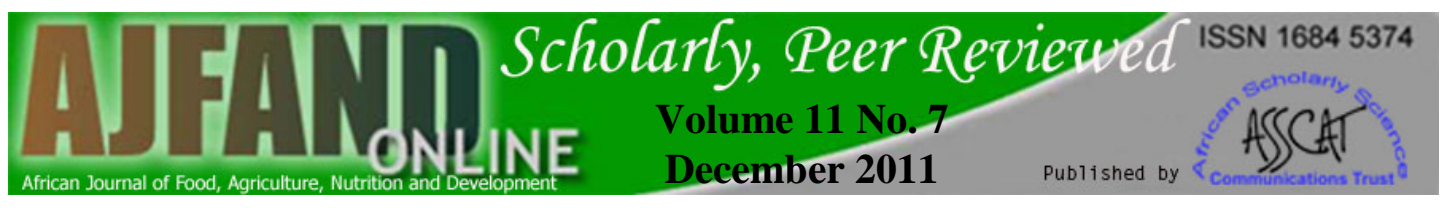

Table 1: Effective Moisture Diffusivity Coefficients for the Different Process Conditions

\begin{tabular}{|c|c|c|c|}
\hline Drying Temperature $\left({ }^{\circ} \mathrm{C}\right)$ & Pretreatment & $D_{\text {eff }} \times 10^{-9}$ & $R^{2}$ \\
\hline \multirow[t]{5}{*}{50} & SB & 2.72 & 0.9446 \\
\hline & WB & 2.66 & 0.9425 \\
\hline & PB & 2.66 & 0.9386 \\
\hline & GB & 2.41 & 0.919 \\
\hline & UB & 2.34 & 0.9529 \\
\hline \multirow[t]{5}{*}{60} & SB & 2.79 & 0.979 \\
\hline & WB & 2.72 & 0.9828 \\
\hline & $\mathrm{PB}$ & 2.72 & 0.9764 \\
\hline & GB & 2.6 & 0.9365 \\
\hline & UB & 2.47 & 0.9539 \\
\hline \multirow[t]{5}{*}{70} & SB & 3.36 & 0.9759 \\
\hline & WB & 3.23 & 0.9909 \\
\hline & PB & 3.17 & 0.9877 \\
\hline & GB & 3.17 & 0.9801 \\
\hline & UB & 3.1 & 0.9943 \\
\hline \multirow[t]{5}{*}{80} & SB & 3.55 & 0.9645 \\
\hline & WB & 3.48 & 0.9679 \\
\hline & $\mathrm{PB}$ & 3.23 & 0.9751 \\
\hline & GB & 3.23 & 0.9729 \\
\hline & UB & 3.1 & 0.9684 \\
\hline \multirow[t]{5}{*}{90} & SB & 2.98 & 0.9701 \\
\hline & WB & 2.85 & 0.9733 \\
\hline & PB & 2.79 & 0.979 \\
\hline & GB & 2.79 & 0.9691 \\
\hline & UB & 2.79 & 0.9774 \\
\hline
\end{tabular}

Where $\mathrm{D}_{\text {eff }}$ - Effective Moisture Diffusivity Coefficients

$\mathrm{R}^{2}$ - Regression coefficient

SB - Steam blanched samples

WB - Water blanched pepper

PB - Palm oil and water blanched

GB - Groundnut oil and water blanched

UB - Unblanched 


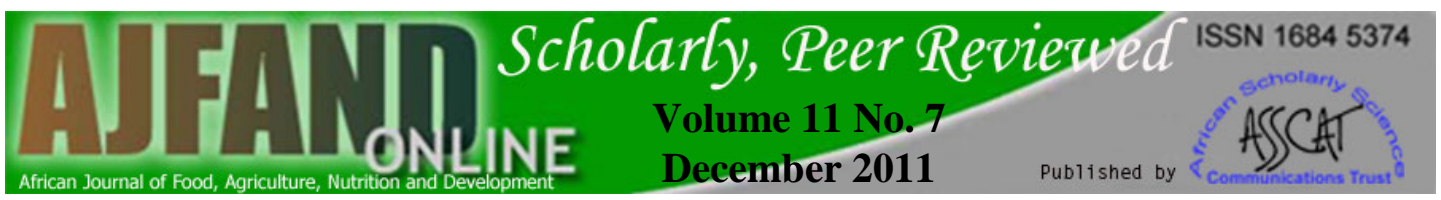

Table 2: Ea values for the drying processes of the different pretreatments for bell pepper

\begin{tabular}{ll}
\hline Pretreatment & Ea (kJ/mol) \\
\hline Steam Blanching (SB) & 61.84 \\
Water Blanching (WB) & 56.38 \\
Palm oil and Water Blanching (PB) & 39.59 \\
Groundnut oil and Water Blanching (GB) & 74.43 \\
Unblanched (UB) & 83.87 \\
\hline
\end{tabular}




\section{REFERENCES}

1 Kordylas JM Processing and Preservation of Tropical and Subtropical Foods. Macmillan Education Ltd, London, UK. 1991.

2 Roberts T and R Cox Drying Fruits and Vegetables. Virginia Cooperative $\begin{array}{llll}\text { Extension } & \text { Publication } & \text { No }\end{array}$ http://www.ext.vt.edu/pubs/foods/348-597/ 348-597.html. Accessed on 15/01/09.

3 Togrul IT and D Pehlivan Mathematical modelling of solar drying of apricots in thin layers. J. Food Eng. 2002; 55: 209-216.

4 Doymaz I Effect of pre-treatments using potassium metabisulphite and alkaline ethyl oleate on the drying kinetics of apricots. Biosys Eng. 2009; 89: 281-287.

5 Kingsly RP, Goyal RK, Manikantan MR and SM Ilyas Effects of pretreatments and drying air temperature on drying behaviour of peach slice. Int. J Food Sci. Tech. 2007; 42: 65-69.

6 Dandamrongrak R, Mason R and G Young The effect of pretreatments on the drying rate and quality of dried bananas. Int J Food Sci Tech. 2003; 38: 877-882.

7 Soysal Y Microwave drying characteristics of parsley. Biosys Engrg. 2004; 89: $167-173$.

8 Akpinar EK and Y Bicer Modelling of the drying of eggplants in thin-layers. Int J Food Sci Tech. 2005; 40: 273-281.

9 Akanbi CT, Olumese AO, Taiwo KA, Ojo A and BA Akinwande Effect of blanching medium on drying and storage characteristics of pepper. Nig. Drying Symp. Series. 2003; 1: 95 - 107.

10 Piga A, Pinna I, Ozer KB, Agabbio M and U Aksoy Hot air dehydration of figs (Ficus carica L.): drying kinetics and quality loss. Int J Food Sci Tech. 2004; 39: 793-799.

11 Tharrington ED, Kendall PA and JN Sofos Inactivation of Escherichia coli O157:H7 during storage or drying of apple slices pretreated with acidic solutions. Int. J. Food Micro. 2005; 99: 79-89.

12 Doymaz I Air-drying characteristics of tomatoes. J. Food Eng. 2007; 78: 1291-1297.

13 Cano P, Marin MA and C Fuster Effects of some thermal treatments on polyphenoloxidase and peroxidase activities of banana (Musa cavendishii, var. enana). J. Sci Food Agric. 1990; 51: 223-231. 


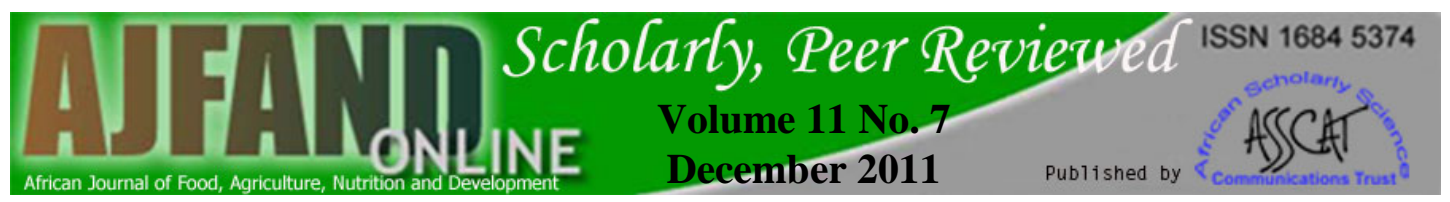

14 Biekman ESA, Kroese-Hoedeman HI and EPHM Schyvens Loss of solute during blanching of mushrooms (Agaricus biosporus) as a result of shrinkage and extraction. J. Food Eng. 1996; 28:139-152.

15 Turhan M, Turhan KN and F Sahbaz Drying kinetics of red pepper. $J$. Food Proc and Pres. 1997; 21: 209-223.

16 Mazza G Drying of carrots: effect of pre-drying treatments on moisture transport and product quality. J. Food Eng. 1983; 18: 113-123.

17 Maskan A, Kaya S and M Maskan Hot air and sun drying of grape leather (pestil). J. Food Eng. 2002; 54: 81 - 88.

18 Karathanos VT and VG Belessiotis Sun and Artificial Air Drying Kinetics of some Agricultural Products. J. Food Eng. 1997; 31 (1): 35 - 46.

19 Pangavhane DR, Sawhney RL and PN Sarsavadia Effect of various dipping pretreatments on drying kinetics of Thompson seedless grapes. J. Food Eng. 1999; 39: $211-216$.

20 Mazza G and ML Maguer Dehydration of onion: some theoretical and practical considerations. J. Food Tech. 1980; 15: 181-194.

21 Kaymak-Ertekin F Drying and Rehydrating Kinetics of Green and Red Peppers. J. Food Sc. 2002; 67 (1): 168-175.

22 Mowlah G, Takano K, Kamoi I and T Obara Water transport mechanism and some aspects of quality changes during air dehydration of bananas. Lebensmittel Wissenshaft und Technologie (LWT). 1983; 16: 103-107.

23 Maskan $\mathbf{M}$ and F Gogus Sorption isotherms and drying characteristics of mulberry (Morus alba). J. Food Eng. 1998; 37: 437-449.

24 Gogus F and M Maskan Water adsorption and drying characteristics of okra (Hibiscus Esculentus L.). Drying Tech. 1999; 17 (4\&5): 883-894.

25 Simal S, Mulet A, Tarrazo J and C Rosello Drying models for green peas. Food Chem. 1996; 55: 121-128.

26 Gupta P, Ahmed J, Shivhare US and GSV Raghavan Drying characteristics of red chilli. Drying Tech. 2002; 20: 1975-1987.

27 Doymaz I Drying characteristics and kinetics of okra. J. Food Eng. 2005; 69: 275-279. 